\title{
Timing of breeding and offspring number covary with plumage colour among Gyrfalcons Falco rusticolus
}

\author{
JEFF A. JOHNSON, ${ }^{1 *}$ \& KURT K. BURNHAM ${ }^{2,3}$ \\ ${ }^{1}$ Department of Biological Sciences, Institute of Applied Sciences, University of North Texas, Denton, TX, USA \\ ${ }^{2}$ High Arctic Institute, Orion, IL, USA \\ ${ }^{3}$ The Peregrine Fund, Boise, ID, USA
}

\begin{abstract}
Plumage colour variation exists among Gyrfalcons throughout their Arctic and sub-Arctic circumpolar distribution, ranging from white through silver and grey to almost black. Although different colour variants coexist within many populations, a few geographical regions, such as northern Greenland, possess a single variant, suggesting that local environments may influence plumage colour variation. In central-west Greenland $\left(66.5-67.5^{\circ} \mathrm{N}\right)$, where multiple colour variants exist, white male Gyrfalcons fathered significantly earlier clutches than grey males. No significant association was observed between female colour and lay date. However, significantly more offspring were produced by both male and female white Gyrfalcons than by grey variants when controlling for lay date, and silver Gyrfalcons produced an intermediate number of offspring for both sexes. This pattern was further supported by breeding plumage colour pairings. Grey females paired with grey males nested significantly later in the season and produced fewer offspring than those paired with white males, whereas no difference in lay date or offspring number was found between white males paired with white or with grey females. The difference in the number of offspring produced at each nest-site was also inversely correlated with the distance to the nearest neighbouring nest, and grey males nested in closer proximity to other nests compared with white and silver colour variants. These results suggest that factors associated with territory occupancy and timing of breeding may regulate reproductive success differently between colour variants, with directional selection favouring light-coloured Gyrfalcons and resulting in earlier lay date and a high frequency of white plumage colour variants in this population. Although gene flow exists between our study population and those further north $\left(>75^{\circ} \mathrm{N}\right)$, white Gyrfalcons prevail where the breeding season duration is even shorter, suggesting that nesting chronology in combination with genetic drift may play an important role in influencing plumage colour polymorphism among Gyrfalcon populations.
\end{abstract}

Keywords: Arctic, colour polymorphism, individual optimization hypothesis, nesting chronology, reproductive success.

\section{INTRODUCTION}

Melanin-based colour variation within and between species normally has a strong genetic component (Hofreiter \& Schöneberg 2010, Manceau et al. 2010). For this reason, coloration has become an important trait for investigating the

*Corresponding author.

E-mail: jajohnson@unt.edu genetic basis of adaptation and phenotypic evolution (e.g. Bortolotti et al. 2008, Anderson et al. 2009, Mullen et al. 2009, Roulin et al. 2010, Jacquin et al. 2011). The evolution of colour polymorphism and its maintenance is largely driven by morph-specific sensitivity to environmental conditions, and the actual mechanism influencing colour variation can vary among species and populations (Galeotti et al. 2003, Roulin 2004a, Bortolotti 2006). 
The degree of pigmentation within endothermic species or among closely related taxa is often positively correlated with humidity (Gloger 1833) or more generally based on proximity to the equator, with lighter coloured individuals typically found closer to the poles (see also Zink \& Remsen 1986, Stoner et al. 2003, Jablonski \& Chaplin 2010). Although animals that possess white plumage or pelage certainly prevail in the Arctic, the potential advantages for the white phenotype are less obvious and may include crypsis (Montgomerie et al. 2001), thermoregulation (Wolf \& Walsberg 2000) and social signalling among conspecifics (Bortolotti et al. 2011). Alternatively, increasing frequency of white plumage with latitude may result from reduced selection pressure on colour (e.g. fewer feather-degrading bacteria; Burtt \& Ichida 2004) and the associated cost of melanin production (Tickell 2003, but see Beauchamp \& Heeb 2001) or pleiotrophic effects associated with genes that determine colour (e.g. Gangoso et al. 2011). Whatever the reason, the causal mechanisms regulating colour polymorphism remain largely unknown and more work is required to describe such patterns and the possible mechanisms that influence their distribution.

To date, no experimental data exist on the factors that may influence colour variation or its adaptive function in the Gyrfalcon Falco rusticolus, a species that exhibits extensive plumage colour variation ranging from white through silver and grey to almost black (Potapov \& Sale 2005, Booms et al. 2008) (Fig. 1). Plumage colour frequencies within Gyrfalcon populations vary throughout their circumpolar Arctic and sub-Arctic distribution, with a few areas possessing a single colour variant. Within Greenland, for example, white Gyrfalcons prevail in the north, whereas multiple plumage colour variants exist further south (Burnham \& Burnham 2011). Although there is no differentiation at neutral genetic markers between these areas, evidence suggests that Gyrfalcon dispersal in Greenland is asymmetric from north to south (Johnson et al. 2007, Burnham \& Newton 2011). Despite connectivity, this asymmetry suggests that factors such as selection intensity may differ between areas and consequently may influence overall plumage colour distribution among Gyrfalcon populations.

For animals breeding in a seasonal environment, the timing of reproduction strongly influences reproductive success, and little work has been done to assess how plumage colour polymorphism may vary with nesting chronology. Temperature, for example, can provide a cue as to when to initiate egg-laying to coincide with favourable conditions (Visser et al. 2009) or may influence the costs of reproduction (Visser \& Lessells 2001, Vézina \& Williams 2002, Williams \& Ames 2004). Temperature may also influence lay date through the ability of the male to acquire sufficient amounts of food to subsist and provision the female with prey while she is producing and incubating eggs. The specific response within populations can vary both geographically and temporally because the costs associated with reproduction and maintenance depend on factors specific to a particular environment, and lower temperatures can make those activities more costly (Newton 1998, Stevenson \& Bryant 2000). In the Arctic, clutch initiation is constrained by limited food availability early in the breeding season and the short time period available to initiate and successfully raise offspring (Drent 2006), particularly among 'income' breeders in which nutrients required for egg production are obtained on breeding territories (Klaassen et al. 2006). Here, we explore potential correlates of plumage colour variation in Gyrfalcon populations, specifically to assess whether melaninbased coloration covaries with nesting chronology and reproductive success in central-west Greenland.

\section{METHODS}

An area of approximately $4250 \mathrm{~km}^{2}\left(66.5-67.5^{\circ} \mathrm{N}\right)$ near Kangerlussuaq in central-west Greenland was surveyed for breeding Gyrfalcons between 1998 and 2006. When breeding Gyrfalcons were observed, nests were accessed and young were ringed using a standard Danish numbered lock-on metal ring and colour ring (ACRAFT, Edmonton, Canada). No ringed chicks were observed in subsequent breeding seasons. Six adult Gyrfalcons were trapped and ringed but only a single female was observed in multiple breeding seasons during the study period (see also Burnham \& Newton 2011).

Because specific nest locations can vary between years depending on the number of suitable cliff ledges or presence of abandoned Common Raven Corvus corax nests in a particular area or cliff face, nests were defined as 'nest-sites' that consisted of a single cliff or adjacent cliffs $(\leq 1 \mathrm{~km})$ where no more than a single Gyrfalcon pair was observed 


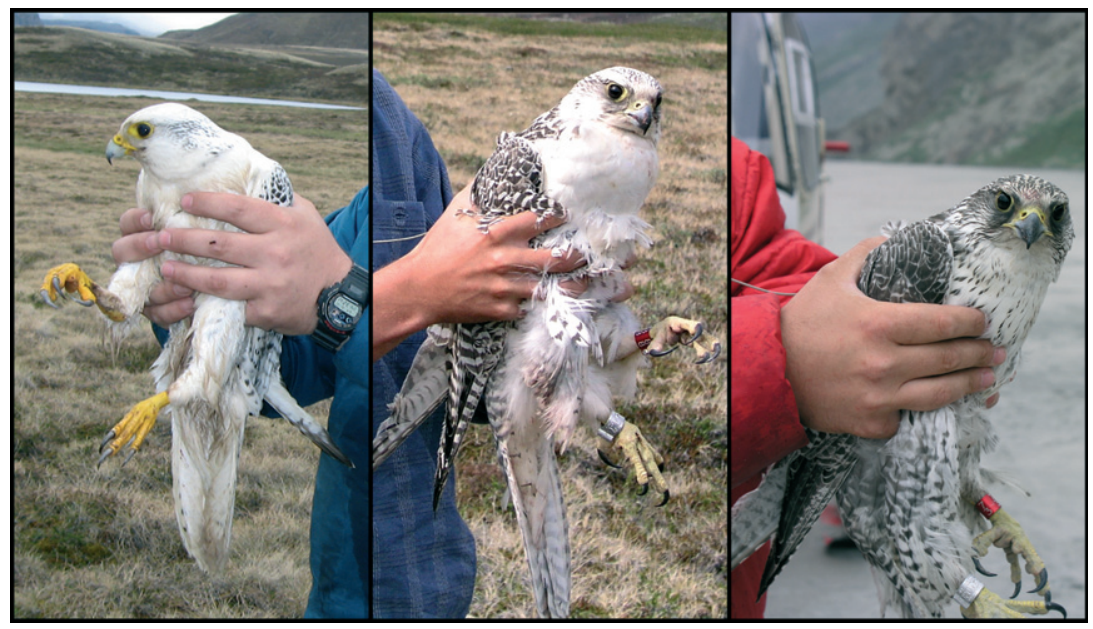

Figure 1. Gyrfalcon plumage colour variants (white, silver and grey) from Kangerlussuaq, Greenland. Photos by Kurt Burnham.

nesting concurrently within the same breeding season. Because Gyrfalcons show high nest-site fidelity (Nielsen 1991, Booms et al. 2011), potential pseudoreplication in the dataset was addressed by conducting additional analyses using data from a single year for pairs at a nest-site that possessed identical plumage colour combinations across multiple breeding seasons for the duration of this study.

Genetically derived melanic (eumelanin) plumage colour variants among Gyrfalcons in Kangerlussuaq are easily assigned to distinct 'background colour' morphs: white, silver or grey (Fig. 1; see also Potapov \& Sale 2005, Booms et al. 2008, Chang et al. 2010), which mostly possess distinct melanocortin-1 receptor (MClR) genotypes (Johnson et al. 2012). Background plumage colour for both breeding adults was recorded at each nest $(n=66)$, with the exception of 15 nests where only the female colour was documented. Gyrfalcon feathers can also possess brown, grey or black markings such as streaks, spots and bars that can vary between individuals relative to the background colour of the feathers. However, the extent of plumage markings was not used in these analyses because it is not known to what degree this trait varies between successive moults (i.e. yearly), whereas adult Gyrfalcons maintain the same background plumage colour throughout their lifespan (Booms et al. 2008). Our field season commenced each year after eggs had hatched, and plumage colour data from nests that failed prior to our arrival were not available.
Nesting chronology was determined by backdating to the first egg-lay date based on the age of chicks (determined by body size and feather growth) at each nest, assuming that an egg was laid every other day, that incubation began with the laying of the third egg and that the incubation period lasted 35 days (Platt 1977, Booms et al. 2008, C. Sandfort pers. comm.). To examine assortative pairing based on plumage colour, expected frequencies of plumages of breeding pairs were generated assuming random mating given the observed frequencies of plumages.

Linear mixed-effects models with restricted maximum-likelihood (REML) were used to assess whether lay date was associated with plumage colour. Julian lay date was included as a dependent variable with nest-site and year fitted as random factors. Male and female plumage colour and their interaction were included in the model as fixed factors. To assess the correlation between plumage colour of both male and female in breeding pairs and lay date, a similar model was used with the same random factors but with plumage colour pair (e.g. white-white, white-grey, etc.) as a fixed factor. Male plumage colour was scored before the female in each breeding pair for data analysis. Differences between colour variants were tested with estimated marginal means.

Differences in the number of offspring $(0,1,2$, $3,4)$ as a function of plumage colour, lay date and year were tested using a generalized linear model (GZLM) with a Tweedie distribution and identity link function. The full models were reduced by 
sequentially excluding the variables that did not explain a significant proportion of the deviance. Variables significant at $P<0.1$ were included in the final model. All excluded variables were included separately in the final model to confirm that they did not explain significant additional variation. Reported statistics correspond to the variables when included in the final model. Differences between colour variants with respect to offspring number were tested with estimated marginal means.

The difference in offspring number as a function of straight-line distance between surveyed nests within each sample year was tested using Spearman rank correlation to assess whether habitat quality or proximity to neighbouring nests differed among individuals, and could thereby influence offspring number. We assumed that areas with nests in close proximity to each other require sufficient food resources for successful reproduction for both breeding pairs, indicating higher quality habitat. Limited information exists on breeding home-range size of Gyrfalcons, and it is not known whether individuals obtained prey in overlapping territories within our study site. Using satellite telemetry, Burnham and Newton (2011) documented a breeding home-range size of $516 \mathrm{~km}^{2}$ for a single white Gyrfalcon male in the Kangerlussuaq study area. Assuming a symmetrically shaped territory, a distance $\leq 22 \mathrm{~km}$ between nest-sites may indicate overlapping territories. All data were analysed using SPSS ver. 19.0.0.1 (IBM Inc., Armonk, NY, USA) and the level of significance was adjusted to account for multiple comparisons with sequential Bonferroni adjustment.

\section{RESULTS}

A total of 60 white (51\%), 22 silver (19\%) and 35 grey (30\%) adult Gyrfalcons were observed in our study area, which contained 74 total nest-sites (see also Burnham \& Burnham 2011). Using count data only for grey and white colour variants due to a limited sample size of silver variants within years $(<5$ individuals), no significant variation in plumage colour frequencies among years was observed (Pearson's chi-squared test: $\chi_{7}^{2}=4.37, P=0.736$ ) but white plumage was more common among male $(67 \%)$ than female (39\%) Gyrfalcons $\left(\chi_{2}^{2}=8.62, P=0.013\right.$; Fig. 2).

There was no statistical evidence that Gyrfalcons formed pairs with respect to plumage colour based on pairs observed after eggs had hatched: (a)
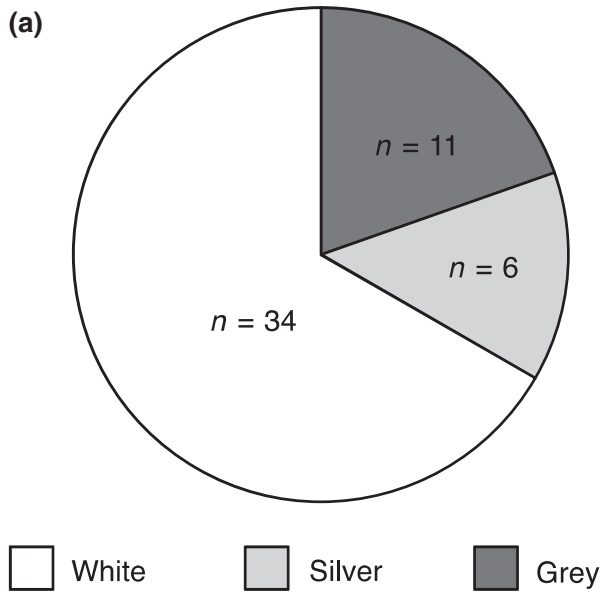

(b)

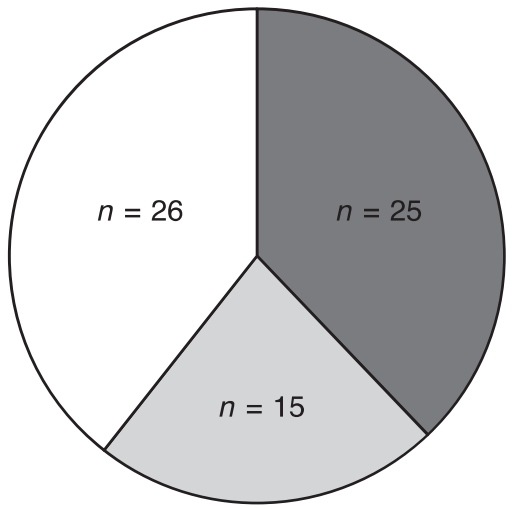

Figure 2. Frequency of plumage colour variants among adult (a) male and (b) female Gyrfalcons observed in Kangerlussuaq.

$78 \%(18 / 23)$ of white females, $70 \%(7 / 10)$ of silver females, and $50 \%(9 / 18)$ of grey females paired with a white male, while $13 \%(3 / 23)$ of white females, 30\% (3/10) of silver females and $28 \%(5 / 18)$ of grey females paired with a grey male $\left(\chi_{4}^{2}=5.69, P=0.223\right)$. Similarly, based on light (white, silver) vs. dark (grey) plumage comparisons, no statistical support for assortative pairing was observed: $82 \%$ (27/33) of light females and $72 \%(13 / 18)$ of dark females paired with light-coloured males $\left(\chi_{1}^{2}=0.63, P=0.426\right)$.

Differences existed between sexes with respect to nesting chronology and plumage colour; those nesting later in the season produced fewer offspring. Nests with white males were initiated significantly earlier than those with grey males (pairwise comparisons of the estimated marginal means, $d f=35.625, P=0.030$; Fig. 3a), although no difference was observed between white and 

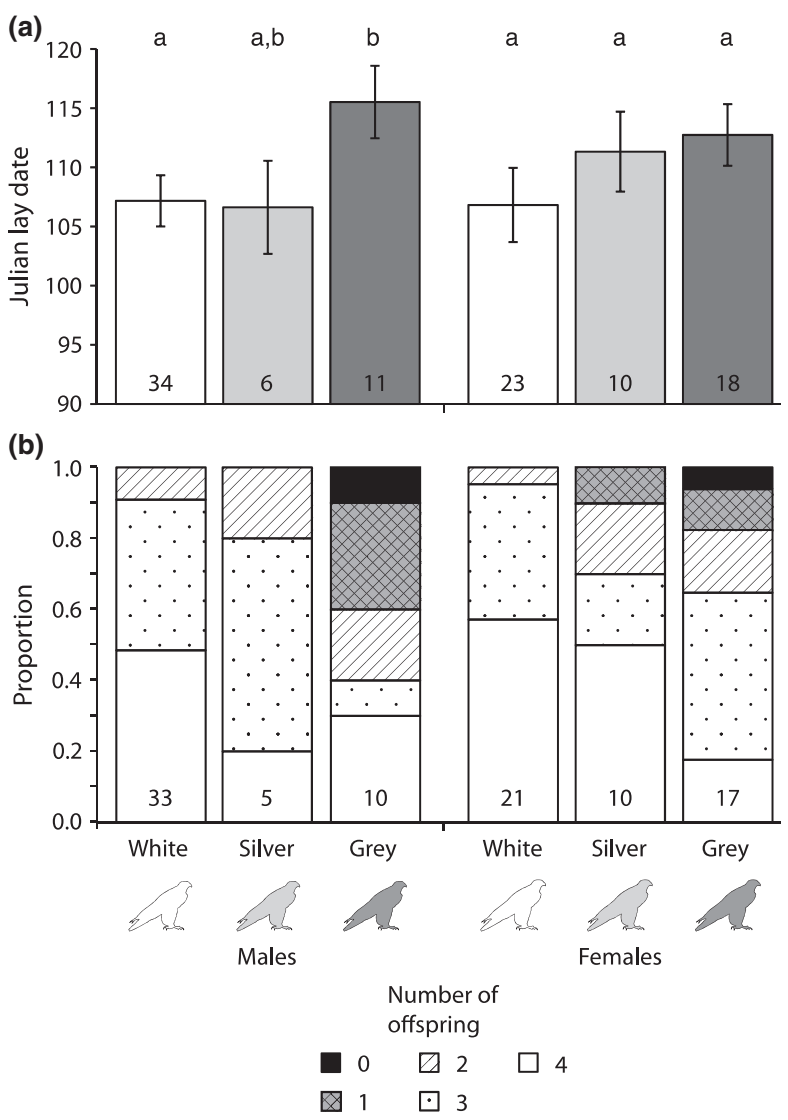

Figure 3. (a) First egg-lay date and (b) proportion with zero, one, two, three, and four offspring for both male (left) and female (right) Gyrfalcons based on plumage colour from the whole sample. Data are estimated marginal means from the model \pm se; different letters at the top indicate significant pairwise comparisons for each sex separately. Sample sizes are given at the base of each bar. Offspring number was not known for all nests; hence, sample sizes differ between (a) and (b).

silver lay dates $(\mathrm{df}=38.973, P=0.990)$ and silver and grey $(\mathrm{df}=36.695, P=0.160)$ male lay dates after adjusting significance for multiple comparisons (Table 1). Additionally, no significant relationship was observed between lay date and female plumage colour or male*female colour interaction. The number of offspring at each nest differed among colour variants for both males and females, but did not vary with lay date or year (Table 2), with a higher proportion of white Gyrfalcons having four offspring compared with silver and grey colour variants (Fig. 3b). Overall, both male and female white Gyrfalcons produced more offspring (estimated marginal mean \pm se $=3.34 \pm 0.13$ and $3.32 \pm 0.24$, respectively) compared with grey Gyrfalcons
Table 1. Results of the mixed models explaining variability in lay date in relation to colour variant in male and female Gyrfalcons, including a separate model for breeding pair plumage colour combinations. Both lay date and year are included as random factors in both models. Significant results $(P<0.050)$ are shown in bold.

\begin{tabular}{lccc}
\hline & \multicolumn{3}{c}{ Lay date } \\
\cline { 2 - 4 } Fixed effects & $F$ & df & $P$ \\
\hline Male colour & $\mathbf{3 . 9 0 6}$ & $\mathbf{2 , 3 6 . 0 2}$ & $\mathbf{0 . 0 2 9}$ \\
Female colour & 1.491 & $2,36.00$ & 0.239 \\
Male*female colour & 1.374 & $3,28.87$ & 0.271 \\
Breeding pair colour & $\mathbf{2 . 7 4 6}$ & $\mathbf{7 , 3 0 . 5 0}$ & $\mathbf{0 . 0 2 5}$
\end{tabular}

Table 2. Generalized linear models (GZLM) investigating the effects of lay date, year, and plumage colour for each sex on offspring number. Breeding pair plumage colour combinations were included in a similar GZLM model, excluding plumage colour variables for each sex. Final models after sequentially eliminating non-significant variables are shown in bold. Statistics of excluded variables are those from separate inclusion in the final model.

\begin{tabular}{lccc}
\hline & \multicolumn{3}{c}{ Offspring number $^{\dagger}$} \\
\cline { 2 - 4 } & $\chi^{2}$ & df & $P$ \\
\hline Lay date & 0.825 & 1 & 0.364 \\
Year & 0.282 & 1 & 0.595 \\
Male colour & $\mathbf{7 . 9 1 8}$ & $\mathbf{2}$ & $\mathbf{0 . 0 1 9}$ \\
Female colour & $\mathbf{7 . 3 1 3}$ & $\mathbf{2}$ & $\mathbf{0 . 0 2 6}$ \\
Lay date & 0.702 & 1 & 0.402 \\
Year & 0.005 & 1 & 0.942 \\
Breeding pair colour & $\mathbf{8 . 0 8 2}$ & $\mathbf{3}$ & $\mathbf{0 . 0 4 4}$ \\
\hline
\end{tabular}

${ }^{\dagger}$ Male*female colour interaction not included in model due to breeding pair plumage colour sample size limitations (see Results).

$(2.21 \pm 0.38$ and $2.43 \pm 0.24$, respectively; male: $P=0.015$; female: $P=0.021$ ). The number of offspring produced by silver Gyrfalcons (males: $3.23 \pm 0.34$; females: $3.03 \pm 0.37$ ) did not differ from those produced by white or grey individuals $(P>0.100)$ after controlling for multiple comparisons. Similar results were obtained after eliminating the single grey-grey pair that failed, with both male (Wald $\chi_{2}^{2}=7.722, P=0.021$ ) and female $\left(\chi_{2}^{2}=5.900, P=0.052\right)$ plumage colour showing a significant correlation with offspring number while controlling for lay date and year. Similar results were also observed when limiting the analyses to only those pairs with unique plumage colour 
combinations at a particular nest-site $(n=38$; J.A. Johnson unpubl. data).

Although a GZLM for offspring number for all sampled breeding pairs revealed a significant male*female colour interaction $\left(\chi_{3}^{2}=18.17\right.$, $P=0.001)$, this interaction was not significant $\left(\chi_{2}^{2}=3.43, P=0.180\right)$ after eliminating breeding pair colour variants with $<5$ pairs (i.e. $s-\mathrm{w}, \mathrm{s}-\mathrm{g}$, g-w, g-s; see Fig. 4), whereas male colour remained significant $\left(\chi_{1}^{2}=6.61, P=0.010\right)$. These findings suggest that the significant male*female plumage colour interaction with offspring number in the complete dataset was partly the result of sampling error due to small sample sizes.

When considering the plumage colour of both adults at each nest as a single factor, a significant

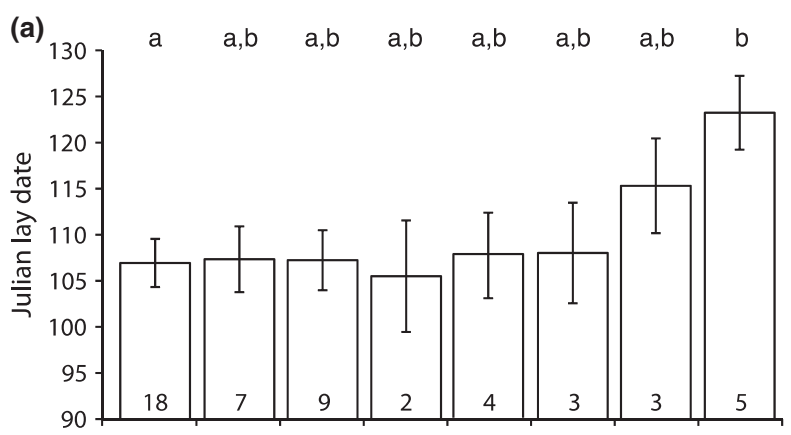

(b)

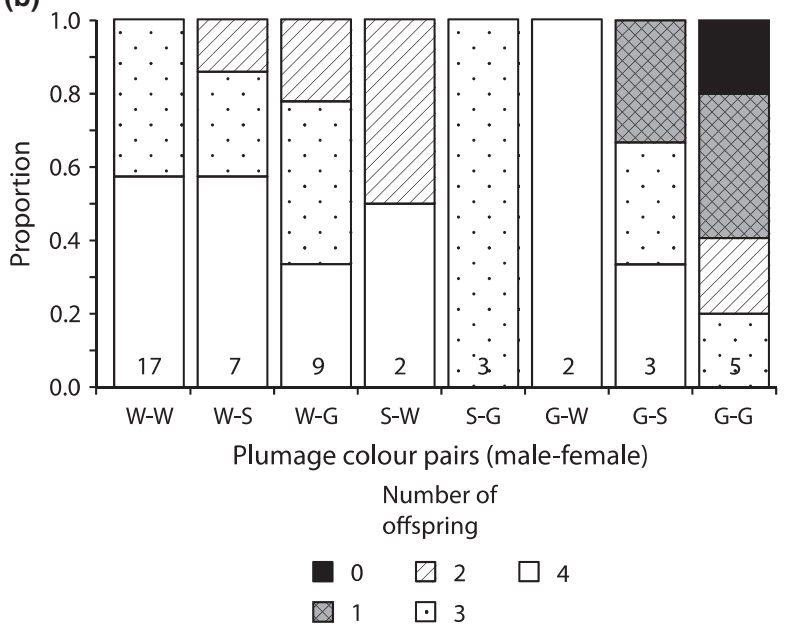

Figure 4. Breeding pair (a) first egg-lay date and (b) proportion with zero, one, two, three or four offspring as a function of plumage colour variants based on the complete sample. Male colour given first; w, white; s, silver; g, grey; e.g. w-s = white male, silver female. Lay dates are estimated marginal means from the model \pm se; different letters at top indicate significant pair wise comparisons. Sample sizes are given at the base of each bar. Offspring number was not known for all nests; hence, a few sample sizes differ between (a) and (b). effect was observed between breeding pair plumage colour combinations and both lay date (Table 1) and offspring number (Table 2); however, the effect differed between the sexes. Limiting the analysis to only those plumage pairs with $\geq 5$ nests, grey females paired with grey males nested significantly later in the season (estimated marginal mean \pm se Julian date $=$ $122.32 \pm 3.87 ; \quad P=0.001)$ and produced fewer offspring (1.29 $\pm 0.85 ; P=0.032)$ compared with those paired with white males $(106.18 \pm 2.94$; $2.82 \pm 0.35$, respectively), whereas white males paired with white females did not differ in lay date $(106.48 \pm 2.31 ; P=0.928)$ or offspring number $(3.42 \pm 0.14 ; P=0.067)$ with those paired with grey females (Fig. 4). Similar results were obtained after eliminating the single grey-grey pair that failed to fledge chicks and including only a single year from pairs with identical plumage colour combinations across multiple years at a particular nest-site (unpubl. data). No silver-silver nest pairs were observed.

The distance between nest-sites within a given breeding season was also inversely correlated with the difference in the number of offspring $\left(r_{\mathrm{s}}=-0.189, \quad n=135, \quad P=0.028\right)$, whereas the number of days between lay dates was not correlated with distance between nests $\left(r_{\mathrm{s}}=0.11, n=145\right.$, $P=0.196)$. The mean straight-line distance between pairwise nest locations within each year surveyed ranged from $42.3 \mathrm{~km}(\mathrm{sd}=23.4, n=7)$ in 1999 to $63.6 \mathrm{~km}(\mathrm{sd}=21.9, n=5)$ in 2006, whereas the minimum distance in a given year ranged from 5.3 to $25.5 \mathrm{~km}$ (mean $\pm \mathrm{sd}=11.8 \pm 5.8$ ), suggesting that overlapping territories were possible when considering satellite telemetry results from Burnham and Newton (2011).

On average, a shorter distance to the nearest nest was documented for nests occupied by grey males (mean $\pm \mathrm{se}=16.33 \pm 2.19 \mathrm{~km}$ ) compared with white males $(24.91 \pm 2.64 \mathrm{~km}$; Mann-Whitney $U$-test, $Z=-1.95, P=0.050)$ in a given breeding year, whereas the mean distance to the nearest nest among silver male nests $(20.51 \pm 4.69 \mathrm{~km})$ was not significantly different from those recorded for both white $(Z=-0.49, \quad P=0.625)$ and grey males $(Z=-0.74, P=0.513$; Fig. 5). For female nesting Gyrfalcons, no significant difference in mean distance to the nearest nest was observed among the three plumage colour variants (grey $=22.66 \pm$ $3.05 \mathrm{~km}$; silver $=20.07 \pm 3.92 \mathrm{~km}$; white $=23.80$ $\pm 3.34 \mathrm{~km} ; P>0.410)$. 


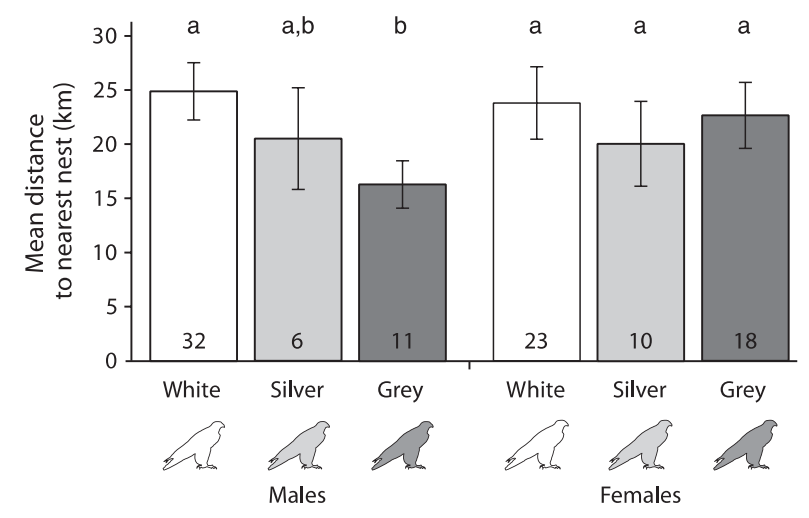

Figure 5. Mean distance to nearest nest for each sex and plumage colour variant. Different letters at the top indicate significant pairwise comparisons for each sex separately. Sample sizes and standard error bars are given for each colour variant.

\section{DISCUSSION}

In central-west Greenland, first-egg lay date differed at Gyrfalcon nests with respect to plumage colour for males but not females. Lay date for white male Gyrfalcons was earlier than for grey males, whereas no significant effect was observed with lay date and colour among females. Despite these differences between sexes, a significant effect on lay date was observed relative to the plumage colour of breeding pairs, where grey females paired with grey males nested significantly later than those paired with white males, whereas lay date for white males paired with white females did not differ from those paired with grey females. Later lay dates also resulted in reduced reproductive success, grey Gyrfalcons producing fewer offspring, many of which were associated with nests in closer proximity to neighbouring territories, compared with light-coloured Gyrfalcons. These results therefore suggest that the effect of plumage colour differed between the sexes, with male plumage colour having a larger effect on lay date and offspring number than that observed with female plumage colour. This is the first time that plumage colour within a Gyrfalcon population has been shown to covary with nesting chronology and sex, and thereby provides a potential mechanism for maintaining a population's plumage colour frequency.

\section{Assortative pairing}

Within harsh environments such as the Arctic, where energy demands are high, extreme temper- atures and a short breeding season may limit reproductive success (Martin \& Wiebe 2004, Drent 2006) and directional selection resulting in egg lay date differences based on plumage colour may influence the relative frequency of colour variants in Gyrfalcon populations. Similar to Arctic Skuas Stercorarius parasiticus (O'Donald 1980), assortative pairing, for example, may influence lay date with respect to plumage colour in Kangerlussuaq's Gyrfalcon population by females preferentially mating with white males; however, no statistical support for this hypothesis was observed. Alternatively, other aspects associated with the Arctic environment may influence plumage colour distribution relative to lay date.

\section{Individual quality and access to prey}

Since Perrins (1970), much work has been done to investigate factors influencing breeding chronology in birds, most documenting a consistent seasonal decline in fitness once the optimal egg-laying period has been passed (Drent 2006). In many cases, food supplementation in the field resulted in a positive response with lay date, i.e. individuals receiving food initiating and laying eggs earlier (Svensson 1995, Meijer \& Drent 1999, Drent 2006, Verhulst \& Nilsson 2008, Barichello \& Mossop 2012). These experiments, along with others investigating various costs associated with early lay date and the effects of brood size manipulations, support the individual optimization hypothesis of Drent and Daan (1980) where the 'timing of egg laying is a "personal" decision of the individual pair geared to the territory and parental capabilities ("quality")' (Drent 2006). As such, our data suggest that 'quality' may covary with Gyrfalcon plumage colour, thereby influencing optimal lay date and reproductive success.

Although there is no direct evidence that Gyrfalcon hunting success depends on plumage colour, crypsis may increase access to potential prey depending on the environment and thereby influence individual quality (Roulin 2004b, Anderson et al. 2009), particularly during the early breeding season when prey are limited. In Kangerlussuaq, Gyrfalcon lay date from 1998 to 2006 ranged from 28 March to 9 May (mean = 17 April; Burnham \& Burnham 2011), with Rock Ptarmigan Lagopus muta, Snow Bunting Plectrophenax nivalis and Arctic Hare Lepus arcticus being the primary prey available early in the breeding season (Salomonsen 
1950, Boertmann 1994, K. Burnham unpubl. data). Although no published information is available on Gyrfalcon diet during or prior to incubation in this area, Booms and Fuller (2003a,b) documented increasing numbers of smaller prey, such as Arctic Hare leverets and juvenile passerines (e.g. Plectrophenax nivalis, Calcarius lapponicus), obtained by males throughout the nestling period. Female Gyrfalcons, in contrast, continue to prey predominantly on Rock Ptarmigan throughout the breeding season (Booms \& Fuller 2003a). Because male Gyrfalcons are smaller than females (Booms et al. 2008), differences may exist between sexes in their ability to obtain large prey such as Rock Ptarmigan. Therefore, body size differences may help to explain why variation existed between the sexes with respect to lay date and plumage colour.

Variability in courtship behaviors such as nestsite attendance, ledge and aerial displays, timing and frequency of copulations, and the number of food transfers by the male to the female also exist within Gyrfalcon populations (Booms et al. 2008) and may be used as a signal for male quality prior to nest initiation. For example, based on a study investigating male courtship behaviour in a Gyrfalcon population in the central Yukon, increased frequency of male courtship feeding was correlated with earlier nest initiation and/or reduced nest failure (Barichello 2012). Males that delivered more prey to the female prior to incubation experienced reduced female abandonment, or higher nesting success, suggesting that provisioning rate may serve as a reliable indicator of male quality, allowing the female to remain inactive and accumulate fat reserves necessary for egg production and incubation (Barichello 2012, see also Galván \& Sanz 2011). Similar results have also been documented for Peregrine Falcon Falco peregrinus (Olsen et al. 1998) and Osprey Pandion haliaetus (Green \& Krebs 1995).

Although only based on two Gyrfalcon nestsites in our study area, the amount of daily biomass delivered to the nest by adult males differed depending on plumage colour. The grey male delivered $15 \%$ of total prey items, whereas the white male delivered 63\% (Booms \& Fuller 2003b, T. Booms pers. comm.). Reduced parental provisioning has also been observed in male Barn Owls Tyto alba with large black spots relative to smallspotted males (Almasi et al. 2008). In open habitats like those in Kangerlussuaq, or the Arctic in general, white Gyrfalcons may be more cryptic against a bright sky, whereas dark individuals may be more obvious to prey (see also Galeotti et al. 2003, Green \& Leberg 2005, Klinka \& Reimchen 2009). The combination of limited prey early in the breeding season and a Gyrfalcon's ability to obtain prey may therefore be an important constraint regulating plumage colour frequency relative to nesting chronology (e.g. Skülason \& Smith 1995).

\section{Habitat quality}

Alternatively, plumage colour may correlate with individual 'quality' based on prey availability within their occupied breeding territories, where the highest quality individuals, or those to arrive first, occupy the highest quality sites (Fretwell \& Lucas 1970, see also Newton 1998). High-quality territories with superior food supply allow females to spend more time on eggs (Zimmerling \& Ankney 2005), which is advantageous in a cold environment for optimal embryo development (Matysioková \& Remeš 2010). Because our field season began after eggs hatched, it is not known if the timing of territory establishment and early season nest initiation differed based on male plumage colour. To our knowledge, there is no evidence that the timing of migration covaries with plumage colour in Gyrfalcon. It is also not known whether a higher frequency of grey compared with white males abandoned their nests prior to our census date, or how prey availability, particularly Rock Ptarmigan, differed among nest-site territories. Therefore, we are unable to assess directly whether plumage colour is correlated with individual or habitat quality, thereby influencing nesting chronology.

The spacing of breeding site territories relative to plumage colour may provide an indirect assessment of habitat quality, or at least a measure of the ability of a territory to provide the necessary prey required for reproduction (e.g. Arcese \& Smith 1988, Bonal \& Aparicio 2008). For example, a study of Peregrine Falcons in Kangerlussuaq documented a significant positive correlation between the number of offspring produced and distance to the nearest nesting cliff (Wightman \& Fuller 2006). A similar pattern was also observed with Gyrfalcons in this study. These results suggest that factors such as habitat quality or prey availability associated with overlapping territories depending on the timing of breeding may influence reproductive success among Gyrfalcons. 
Interestingly, when considering nest-sites in close proximity to each other $(\leq 22 \mathrm{~km}), 19$ of $22(86 \%)$ possessed either males with identical plumage colour $(n=8)$ or the lighter coloured male was associated with the earlier lay date $(n=11)$. Two pairwise nest comparisons had silver males nesting earlier than white males and a third comparison had a grey male nesting earlier than a silver male. Given that the difference in offspring number between two neighbouring nests decreased as geographical distance increased and grey males, including grey-grey pairs, typically nested later than white males, these results suggest that nestsites may be limited and grey Gyrfalcons may have no choice but to nest in close proximity to active nests, thereby affecting their overall productivity (i.e. density-dependent or interference competition; see also Wightman \& Fuller 2006). In fact, this appears to be the case, with grey males on average nesting in closer proximity to other nests compared with white males (Fig. 5). It is important to note that Gyrfalcon territories are likely to vary in size depending on the cyclical abundance of Ptarmigan (e.g. Nielsen 2012, see also Newton 1998) and therefore these patterns may change depending on prey availability.

Additional factors that may influence Gyrfalcon reproductive success relative to habitat quality include interspecific interactions with Peregrine Falcons that nest in close proximity to Gyrfalcons. Although Gyrfalcons arrived at nest-sites and initiated egg-laying on average 45 days earlier than Peregrines (Julian date: 107 vs. 152, Burnham et al. 2011, unpubl. data), interspecific competition for both nest-sites, through aggressive interactions (Burnham 2008), and prey, particularly passerines (Burnham \& Mattox 1984, Rosenfield et al. 1995, Booms \& Fuller 2003b, Burnham \& Burnham 2011, see also Pokrovsky et al. 2010), is likely to occur at our study site. During this study, only 12 days separated the latest and earliest Gyrfalcon and Peregrine lay dates, respectively (unpubl. data), suggesting that the greatest competition with Peregrines is most likely to occur with Gyrfalcons that initiate their nests late in the season (i.e. grey males). The extent to which interactions with Peregrines influence Gyrfalcon productivity warrants further study. Additional work is also needed to determine whether lay date corresponds with recruitment, with an earlier lay date correlated with higher recruitment, similar to Peregrine Falcons (Restani \& Mattox 2000).

\section{Genetic factors}

Despite the reduced number of offspring for grey variants, dark-coloured Gyrfalcons in Kangerlussuaq are likely to persist due to inheritance patterns associated with genes that determine plumage colour (Chang et al. 2010). For example, Johnson et al. (2012) identified a strong correlation between allelic variants that possessed differing amino acid substitutions at MC1R and the white/ melanic plumage colour among Gyrfalcons. White Gyrfalcons appeared homozygous recessive for MC1R, whereas all silver Gyrfalcons were heterozygous, and grey Gyrfalcons were either heterozygous or homozygous dominant (Johnson et al. 2012, see also Zhan et al. 2012). Therefore, because silver Gyrfalcons were similar to white variants with respect to timing of breeding and reproductive success for both sexes, the melanic allele is unlikely to be eliminated in the Kangerlussuaq population, thereby providing a mechanism to maintain grey Gyrfalcons regardless of reduced reproductive potential.

\section{Broader implications of plumage colour distribution in Greenland}

These results have further implications for why plumage colour varies throughout the species' distribution, particularly within Greenland. Because melanic plumage colour is strongly heritable (Chang et al. 2010, Johnson et al. 2012) and a small window of opportunity exists in the Arctic for raising and fledging young, the positive correlation in Greenland between the frequency of white Gyrfalcons and latitude may, therefore, be the result of local adaptation and increasing directional selection intensity on lay date (see also Antoniazza et al. 2010).

Using similar sampling years, the timing of Gyrfalcon nest initiation was approximately 18 days earlier in Kangerlussuaq (mean lay date $=107.4$, $\mathrm{sd}=9.4, n=70$; this study) than in the Thule population $c .1200 \mathrm{~km}$ to the north (date $=125.0$, $\mathrm{sd}=7.0, n=40$; Burnham \& Burnham 2011). The Kangerlussuaq Gyrfalcon population also exhibited a much wider range of dates for the nesting period duration. For example, fledging dates in Kangerlussuaq ( $n=66$ nests) between 1998 and 2006 occurred over a 43-day period, compared with 31 days among nests in Thule ( $n=40$, 1994-2010; Burnham \& Burnham 2011). In combination with the effects of low immigra- 
tion and genetic drift (Johnson et al. 2007), the overall duration of the breeding season in north Greenland (e.g. Thule) may be too short to maintain dark-coloured Gyrfalcons given potential limitations associated with reduced reproductive success and small population size (see also Hedrick \& Ritland 2012). In contrast, the longer breeding season further south may confer a selective advantage to alternative phenotypes depending on the environment and therefore allow grey plumage variants to persist (e.g. Sirkiä et al. 2010).

Between 1993 and 2010 only a single melanic (grey) female and her offspring were observed in Thule, whereas all other surveyed Gyrfalcons $(n=285)$ were white (Burnham \& Burnham 2011). Based on neutral markers, the Thule population has reduced levels of genetic diversity compared with Kangerlussuaq (Johnson et al. 2007), suggesting that drift in combination with low immigration may also limit plumage colour variability in this species. No silver Gyrfalcons have been observed to date in Thule, and the single observed grey female and her offspring did not return during subsequent breeding seasons. More work is needed to assess whether similar patterns in nest chronology and plumage colour exist in Gyrfalcon populations elsewhere in their circumpolar distribution.

We thank Bill Burnham, Brian and Ruth Mutch, Bill Heinrich, Travis Booms, Greg Doney, Catherine Wightman and Alberto Palleroni for their assistance in the field. We are also grateful to Peter Dunn for providing advice concerning statistical methods, and Tom Cade, Ian Newton, and three anonymous reviewers for useful comments on this manuscript. Permits to conduct research were provided by the Greenland Home Rule Government. Financial support was provided by University of North Texas, Wolf Creek Charitable Foundation, The Offield Family Foundation, Ruth O. Mutch and The Peregrine Fund.

\section{REFERENCES}

Almasi, B., Roulin, A., Jenni-Eiermann, S. \& Jenni, L. 2008. Parental investment and its sensitivity to corticosterone is linked to melanin-based coloration in barn owls. Horm. Behav. 54: 217-223.

Anderson, T.M., vonHoldt, B.M., Candille, S.I., Musiani, M., Greco, C., Stahler, D.R., Smith, D.W., Padhukasahasram, B., Randi, E., Leonard, J.A., Bustamante, C.D., Ostrander, E.A., Tang, H., Wayne, R.K. \& Barsh, G.S. 2009. Molecular and evolutionary history of melanism in North American gray wolves. Science 323: 1339-1343.

Antoniazza, S., Burri, R., Fumagalli, L., Goudet, J. \& Roulin, A. 2010. Local adaptation maintains clinal variation in melanin-based coloration of European Barn Owls (Tyto alba). Evolution 64: 1944-1954.

Arcese, P. \& Smith, J.N.M. 1988. Effects of population density and supplemental food on reproduction in song sparrows. J. Anim. Ecol. 57: 119-136.

Barichello, N. 2012. Gyrfalcon courtship - a mechanism to adjust reproductive effort to the availability of ptarmigan. In Watson, R.T., Cade, T.J., Fuller, M., Hunt, G. \& Potapov, E. (eds) Gyrfalcons and Ptarmigan in a Changing World: 339 354. Boise, ID: The Peregrine Fund.

Barichello, N. \& Mossop, D. 2012. The overwhelming influence of ptarmigan abundance on gyrfalcon reproductive success in the central Yukon, Canada. In Watson, R.T., Cade, T.J., Fuller, M., Hunt, G. \& Potapov, E. (eds) Gyrfalcons and Ptarmigan in a Changing World: 307-322. Boise, ID: The Peregrine Fund.

Beauchamp, G. \& Heeb, P. 2001. Social foraging and the evolution of white plumage. Evol. Ecol. Res. 3: 703-720.

Boertmann, D. 1994. An annotated checklist to the birds of Greenland. Meddelelser om Grønland, Bioscience 38: 1-63.

Bonal, R. \& Aparicio, J.M. 2008. Evidence of prey depletion around Lesser Kestrel Falco naumanni colonies and its short term negative consequences. J. Avian Biol. 39: 189-197.

Booms, T.L. \& Fuller, M.R. 2003a. Gyrfalcon diet in central west Greenland during the nesting period. Condor 105: 528-537.

Booms, T.L. \& Fuller, M.R. 2003b. Gyrfalcon feeding behavior during the nestling period in central west Greenland. Arctic 56: 341-348.

Booms, T.L., Cade, T.J. \& Clum, N.J. 2008. Gyrfalcon (Falco rusticolus). In Poole, A. (ed.) The Birds of North America Online. Ithaca, NY: Cornell Lab of Ornithology.

Booms, T.L., Talbot, S.L., Sage, G.K., McCaffery, B.J., McCracken, K.G. \& Schempf, P.F. 2011. Nest-site fidelity and dispersal of Gyrfalcons estimated by noninvasive genetic sampling. Condor 113: 768-778.

Bortolotti, G.R. 2006. Natural selection and coloration: protection, concealment, advertisement, or deception? In Hill, G.E. \& McGraw, K.J. (eds) Bird Coloration, vol. 2. Function and Evolution: 3-35. Cambridge, MA: Harvard University Press.

Bortolotti, G.R., González, L.M., Margalida, A., Sánchez, R. \& Oria, J. 2008. Positive assortative pairing by plumage color in Spanish imperial eagles. Behav. Processes 78: 100-107.

Bortolotti, G.R., Stoffel, M.J. \& Galván, I. 2011. Wintering Snowy Owls Bubo scandiacus integrate plumage colour, behaviour and their environment to maximize efficacy of visual displays. Ibis 153: 134-142.

Burnham, K.K. 2008. Inter- and intraspecific variation of breeding biology, movements, and genotype in Peregrine Falcon Falco peregrinus and Gyrfalcon F. rusticolus populations in Greenland. DPhil Thesis, Oxford, UK: University of Oxford.

Burnham, W.A. \& Mattox, W.G. 1984. Biology of the Peregrine and Gyrfalcon in Greenland. Meddeleser om Gronland, Bioscience 14: 1-28.

Burnham, K.K. \& Newton, I. 2011. Seasonal movements of Gyrfalcons Falco rusticolus include extensive periods at sea. Ibis 153: 468-484. 
Burnham, K.K. \& Burnham, W.A. 2011. Ecology and biology of gyrfalcons in Greenland. In Watson, R.T., Cade, T.J., Fuller, M., Hunt, G. \& Potapov, E. (eds) Gyrfalcons and Ptarmigan in a Changing World: 1-19. Boise, ID: The Peregrine Fund.

Burnham, K.K., Burnham, W.A., Newton, I., Johnson, J.A. \& Gosler, A.G. 2012. The history and range expansion of Peregrine Falcons in the Thule area, northwest Greenland. Meddelelser om Grønland, Bioscience ISBN: 8763539004 ISBN: 9783763539005 (in press).

Burtt, E.H. Jr \& Ichida, J.M. 2004. Gloger's Rule, featherdegrading bacteria, and color variation among Song Sparrows. Condor 106: 681-686.

Chang, V.S., Lejeune, J. \& Cheng, K.M. 2010. The pattern of inheritance of melanin-based plumage color variants in the Gyrfalcon (Falco rusticolus). J. Raptor Res. 44: 224 232.

Drent, R.H. 2006. The timing of birds' breeding seasons: the Perrins hypothesis revisited especially for migrants. Ardea 94: 305-322.

Drent, R.H. \& Daan, S. 1980. The prudent parent: energetic adjustments in avian breeding. Ardea 68: 225-252.

Fretwell, S.D. \& Lucas, H.L. 1970. On territorial behaviour and other factors influencing distribution in birds. Acta Biotheor. 19: 16-36.

Galeotti, P., Rubolini, D., Dunn, P.O. \& Fasola, M. 2003. Colour polymorphism in birds: causes and functions. J. Evol. Biol. 16: 635-646.

Galván, I. \& Sanz, J.J. 2011. Mate-feeding has evolved as a compensatory energetic strategy that affects breeding success in birds. Behav. Ecol. 22: 1088-1095.

Gangoso, L., Grande, J.M., Ducrest, A.-L., Figuerola, J., Bortolotti, G.R., Andrés, J.A. \& Roulin, A. 2011. MC1Rdependent, melanin-based colour polymorphism is associated with cell-mediated response in the Eleonora's Falcon. J. Evol. Biol. 24: 2055-2063.

Gloger, C.L. 1833. Das Abändern der Vögel durch Einfluss des Klimas. Breslau: A. Schultz \& Co.

Green, D.J. \& Krebs, E.A. 1995. Courtship feeding in Ospreys Pandion haliaetus: a criterion for mate assessment? Ibis 137: 35-43.

Green, M.C. \& Leberg, P.L. 2005. Influence of plumage colour on prey response: does habitat alter heron crypsis to prey? Animal Behav. 70: 1203-1208.

Hedrick, P.W. \& Ritland, K. 2012. Population genetics of the white-phased 'spirit' black bear of British Columbia. Evolution 66: 305-313.

Hofreiter, M. \& Schöneberg, T. 2010. The genetic and evolutionary basis of colour variation in vertebrates. Cell. Mol. Life Sci. 67: 2591-2603.

Jablonski, N.G. \& Chaplin, G. 2010. Human skin pigmentation as an adaptation to UV radiation. Proc. Natl Acad. Sci. USA 107(Suppl): 8962-8968.

Jacquin, L., Lenouvel, P., Haussy, C., Ducatez, S. \& Gasparini, J. 2011. Melanin-based coloration is related to parasite intensity and cellular immune response in an urban free living bird: the feral pigeon Columba livia. J. Avian Biol. 42: $11-15$.

Johnson, J.A., Burnham, K.K., Burnham, W.A. \& Mindell, D.P. 2007. Genetic structure among continental and island populations of gyrfalcons. Mol. Ecol. 16: 3145-3160.
Johnson, J.A., Ambers, A.D. \& Burnham, K.K. 2012. Genetics of plumage color in the gyrfalcon (Falco rusticolus): analysis of the melanocortin-1 receptor gene. $\mathrm{J}$. Hered. 103: 315-321.

Klaassen, M., Abraham, K.F., Jefferies, R.L. \& Vrtiska, M. 2006. Factors affecting the site of investment, and the reliance on savings for arctic breeders: the capital-income dichotomy revisited. Ardea 94: 371-384.

Klinka, D.R. \& Reimchen, T.E. 2009. Adaptive coat colour polymorphism in the Kermode bear of coastal British Columbia. Biol. J. Linn. Soc. 98: 479-488.

Manceau, M., Domingues, V.S., Linnen, C.R., Rosenblum, E.B. \& Hoekstra, H.E. 2010. Convergence in pigmentation at multiple levels: mutations, genes and function. Proc. $R$. Soc. B 365: 2439-2450.

Martin, K. \& Wiebe, K.L. 2004. Coping mechanisms of alpine and arctic breeding birds: extreme weather and limitations to reproductive resilience. Integr. Comp. Biol. 44: 177-185.

Matysioková, B. \& Remeš, V. 2010. Incubation feeding and nest attentiveness in a socially monogamous songbird: role of feather colouration, territory quality and ambient environment. Ethology 116: 596-607.

Meijer, T. \& Drent, R. 1999. Re-examination of the capital and income dichotomy in breeding birds. Ibis 141: 399-414.

Montgomerie, R., Lyon, B. \& Holder, K. 2001. Dirty ptarmigan: behavioral modification of conspicuous male plumage. Behav. Ecol. 12: 429-438.

Mullen, L.M., Vignieri, S.N., Gore, J.A. \& Hoekstra, H.E. 2009. Adaptive basis of geographic variation: genetic, phenotypic and environmental differences among beach mouse populations. Proc. R. Soc. B 276: 3809-3818.

Newton, I. 1998. Population Limitations in Birds. London: Academic Press.

Nielsen, Ó.K. 1991. Age of first breeding and site fidelity of Gyrfalcons. Náttúrufræđingurinn 60: 135-143.

Nielsen, Ó.K. 2012. Gyrfalcon population and reproduction in relation to Rock Ptarmigan numbers in Iceland. In Watson, R.T., Cade, T.J., Fuller, M., Hunt, G. \& Potapov, E. (eds) Gyrfalcons and Ptarmigan in a Changing World: 21-47. Boise, ID: The Peregrine Fund.

O'Donald, P. 1980. Sexual selection by female choice in a monogamous bird: Darwin's theory corroborated. Heredity 45: 201-217.

Olsen, P., Doyle, V. \& Boulet, M. 1998. Variation in male provisioning in relation to brood size of Peregrine Falcons Falco peregrinus. Emu 98: 297-304.

Perrins, C.M. 1970. The timing of birds' breeding seasons. Ibis 112: 242-255.

Platt, J.B. 1977. The breeding behavior of wild and captive gyrfalcons in relation to their environment and human disturbance. PhD dissertation, Ithaca, NY: Cornell University.

Pokrovsky, I., LeComte, N., Sokolov, A., Sokolov, V. \& Yoccoz, N.G. 2010. Peregrine Falcons kill a Gyrfalcon feeding on their nestling. J. Raptor Res. 44: 66-69.

Potapov, E. \& Sale, R. 2005. The Gyrfalcon. New Haven, CT: Yale University Press.

Restani, M. \& Mattox, W.G. 2000. Natal dispersal of Peregrine Falcons in Greenland. Auk 117: 500-504. 
Rosenfield, R.N., Schneider, J.W., Papp, J.M. \& Seegar, W. S. 1995. Prey of Peregrine Falcons breeding in west Greenland. Condor 97: 763-770.

Roulin, A. 2004a. The evolution, maintenance and adaptive function of genetic colour polymorphisms in birds. Biol. Rev. Camb. Philos. Soc. 79: 815-848.

Roulin, A. 2004b. Covariation between plumage colour polymorphisms and diet in the Barn Owl Tyto alba. Ibis 146: 509-517.

Roulin, A., Altwegg, R., Jensen, H., Steinsland, I. \& Schaub, M. 2010. Sex-dependent selection on an autosomal melanic female ornament promotes the evolution of sex ratio bias. Ecol. Lett. 13: 616-626.

Salomonsen, F. 1950. Grønlands Fugle/Birds of Greenland. Copenhagen: Ejnar Munksgaard.

Sirkiä, P.M., Virolainen, M. \& Laaksonen, T. 2010. Melanin coloration has temperature-dependent effects on breeding performance that may maintain phenotypic variation in a passerine bird. J. Evol. Biol. 11: 2385-2396.

Skülason, S. \& Smith, T.B. 1995. Resource polymorphisms in vertebrates. Trends Ecol. Evol. 10: 366-370.

Stevenson, I.R. \& Bryant, D.M. 2000. Climate change and constraints on breeding. Nature 406: 366-367.

Stoner, C.J., Caro, T.M. \& Graham, C.M. 2003. Ecological and behavioral correlates of coloration in artiodactyls: systematic analyses of conventional hypotheses. Behav. Ecol. 14: 823-840.

Svensson, E. 1995. Avian reproductive timing: when should parents be prudent? Anim. Behav. 49: 1559-1567.

Tickell, W.L.N. 2003. White plumage. Waterbird 26: 1-12.

Verhulst, S. \& Nilsson, J.-Å. 2008. The timing of birds' breeding seasons: a review of experiments that manipulated timing of breeding. Philos. Trans. R. Soc. B 363: 399-410.
Vézina, F. \& Williams, T.D. 2002. Metabolic costs of egg production in the European starling (Sturnus vulgaris). Physiol. Biochem. Zool. 75: 377-385.

Visser, M.E. \& Lessells, C.M. 2001. The costs of egg production and incubation in Great Tits (Parus major). Proc. R. Soc. B 268: 1271-1277.

Visser, M.E., Holleman, L.J.M. \& Caro, S.P. 2009. Temperature has a causal effect on avian timing of reproduction. Proc. R. Soc. B 276: 2323-2331.

Wightman, C.S. \& Fuller, M.R. 2006. Influence of habitat heterogeneity on distribution, occupancy patterns, and productivity of breeding Peregrine Falcons in central West Greenland. Condor 108: 270-281.

Williams, T.D. \& Ames, C.E. 2004. Top-down regression of the avian oviduct during late oviposition in a small passerine bird. J. Exp. Biol. 207: 263-268.

Wolf, B.O. \& Walsberg, G.E. 2000. The role of plumage in heat transfer processes of birds. Am. Zool. 40: 575-584.

Zhan, X.J., Dixon, A., Fox, N.C. \& Bruford, M.W. 2012. Missense SNP of the MC1R gene is associated with plumage variation in the Gyrfalcon (Falco rusticolus). Anim. Genet. 43: 460-462.

Zimmerling, J.R. \& Ankney, C.D. 2005. Variation in incubation patterns of Red-winged Blackbirds nesting at lagoons and ponds in eastern Ontario. Wilson Bull. 117: 280-290.

Zink, R.M. \& Remsen, J.V. Jr 1986. Evolutionary processes and patterns of geographic variation in birds. Curr. Ornithol. 4: $1-69$.

Received 4 October 2011; revision accepted 4 August 2012. Associate Editor: Keith Tarvin. 